\title{
Optimization of culture media for extracellular expression of streptokinase in Escherichia coli using response surface methodology in combination with Plackett-Burman Design
}

\author{
Mojtaba Aghaeepoor ${ }^{1,2}$, Farzad Kobarfard ${ }^{3}$, Mohammad Reza Akbari Eidgahi ${ }^{1}$, \\ Aliakbar Shabani ${ }^{1}$, Ehsan Dehnavi ${ }^{2}$, Maryam Ahmadi ${ }^{1}$ and Ali Akbarzadeh ${ }^{2 *}$ \\ ${ }^{1}$ Semnan Biotechnology Research Center, Semnan University of Medical Sciences, Basij Blvd, Semnan, ${ }^{2}$ Gene Transfer \\ Pioneers (GTP) Research Group, ${ }^{3}$ Department of Medicinal Chemistry, School of Pharmacy, Shahid Beheshti University of \\ Medical Sciences, Vali Asr Ave, Tehran, Iran
}

*For correspondence: Email: akbarzadeh80@yahoo.com; Tel/Fax: +98-21-88200114

\begin{abstract}
Purpose: To investigate the enhancement of streptokinase extracellular expression in Escherichia coli by adjusting culture media.

Methods: Screening of 10 chemical factors (EDTA, peptone, glycine, triton X-100, glycerol, $\mathrm{K}_{2} \mathrm{HPO}_{4}$, $\mathrm{KH}_{2} \mathrm{PO}_{4}, \mathrm{Ca}^{2+}$ (calcium chloride), yeast and $\mathrm{NaCl}$ ) in order to increase the secretion of extracellular protein was carried out by response surface methodology (RSM). The method was also employed to optimize the concentrations of critical factors that had been determined in the screening step.

Results: The results indicate that glycine, triton $\mathrm{X}-100$ and $\mathrm{Ca}^{2+}$ were the most effective chemical factors in terms of increase in extracellular expression of streptokinase with optimum levels of 0.878 , 0.479 and $0.222 \%$, respectively. Expression of streptokinase under optimum concentrations of critical permeabilizing factors led to a 7-fold increase in the quantity of secreted recombinant protein (5824 $\mathrm{U} / \mathrm{mL})$ compared to the initial level ( $802 \mathrm{U} / \mathrm{mL})$.

Conclusion: The results show that medium optimization using RSM is effective in improving extracellular streptokinase expression. The optimization medium is considered fundamental and useful for efficient production of streptokinase on a large scale.
\end{abstract}

Keywords: Streptokinase, Response surface methodology, Membrane permeabilization, Extracellular secretion

Tropical Journal of Pharmaceutical Research is indexed by Science Citation Index (SciSearch), Scopus, International Pharmaceutical Abstract, Chemical Abstracts, Embase, Index Copernicus, EBSCO, African Index Medicus, JournalSeek, Journal Citation Reports/Science Edition, Directory of Open Access Journals (DOAJ), African Journal Online, Bioline International, Open-J-Gate and Pharmacy Abstracts

\section{INTRODUCTION}

Streptokinase $(\mathrm{SK})$ is a single chain $(47 \mathrm{kDa})$ protein that has received much attention as a commonly used thrombolytic agent for treating cardiovascular disease such as heart attack or stroke [1]. SK is not originally a protease; however on complexation with plasminogen it gives rise to plasmin that can dissolve the fibrin network of a blood clot and solubilize degradation products [2,3]. Heterologous production of SK in Escherichia coli (E. coll), as the most widely used prokaryotic system is useful method for industrial applications [4].

Although heterologous expression in E. coli could bring about numerous advantages, accumulation of the expressed protein in the cytosol as a 
biologically inactive protein aggregate (inclusion body) is a significant problem that could be overcame by extracellular expression (periplasmic space or culture medium) of recombinant protein $[5,6]$. However, recombinant proteins most often fail to translocate across the inner and outer membranes of $E$. coli cells $[7,8]$. Medium optimization is one of the most commonly applied approaches to facilitate translocation through membranes. Some medium supplements such as lysozyme, magnesium, calcium, EDTA, glycine, and triton $\mathrm{X}-100$ could increase membrane permeability and subsequent protein secretion to the culture medium [9-11]. The existence certain values of triton X-100 and glycine in the culture medium had a strong effect on extracellular production and could greatly increase both inner and outer cell membrane permeability [12]. Divalent cations, such as $\mathrm{Ca}^{+2}$ and $\mathrm{Mg}^{+2}$ in medium rich with glycine can effectively protect cells from lysing [13]. EDTA and lysozyme could also be led to enhancement of $E$. coli outer membrane permeability [7]. Use of statistical models such as Response Surface Methodology (RSM) could help to determine effective factors, optimum amounts and possible interactions that are related to permeability of a bacterial membrane. An RSM designs the least number of experiments to achieve these goals.

In a previous study, the synthetic SK gene (GenBank Acc. No. KT156726.1) of Streptococcus pyogenes was successfully cloned into pET21b expression vector, while PelB signal peptide was added to the 5 ' end of the gene to deliver the expressed protein into the periplasm. The conditions required for optimum periplasmic expression were determined using RSM. Experiments were done to determine optimum settings for volume, temperature, agitation speed, cell density, IPTG concentration and duration of induction. The aim of the present study was to screen the main culture supplements involved in membrane permeability of $E$. coli and to optimize their concentrations using RSM.

\section{EXPERIMENTAL}

\section{Microorganism and culture conditions}

Recombinant E. coli BL21 cells harboring SK gene in pET21b (+) expression vector (Novagen, Madison, USA) were used for the protein overexpression [14]. The gene was cloned between Ndel and $B a m H I$ restriction sites with PelB as the leader sequence. A single colony of $E$. coli BL21 (DE3) cells with recombinant plasmid was inoculated into $5 \mathrm{~mL}$ Luria - Bertani (LB) medium containing $100 \mu \mathrm{g} / \mathrm{mL}$ ampicillin and grown at 37 ${ }^{\circ} \mathrm{C}$ overnight and used for inoculation. The expression was done in $5 \mathrm{~mL}$ of LB culture medium supplemented with $100 \mu \mathrm{g} / \mathrm{mL}$ ampicillin, at $37^{\circ} \mathrm{C}, 200 \mathrm{rpm}, 0.28 \mathrm{mM}$ of IPTG addition at cell density of OD600 $=3.4$ and $10 \mathrm{~h}$ of expression induction. Total (using the cells and the culture medium as the specimen) and extracellular (using the culture medium as the specimen) activity of the SK was assayed by chromogenic substrate method [15]. Streptokinase converts plasminogen to plasmin in solution in the absence of fibrin. S-2251 chromogenic substrate (H-D-valyl-L-leucyl-Llysine-p-nitroanilide dihydrochloride; (Sigma, USA)) was used in the chromogenic assay method. The substrate solution included a mixture of $1 \mathrm{~mL}$ of Tris- $\mathrm{HCl}(0.5 \mathrm{M}, \mathrm{pH}=7.4), 1$ $\mathrm{mL}$ of S-2251 (3 mM) and $5 \mu \mathrm{L}$ of Tween 20 (10 $\%$ ). This solution was kept at $37{ }^{\circ} \mathrm{C}$, but immediately before use, $45 \mu \mathrm{L}$ of humanplasminogen solution $(1 \mathrm{mg} / \mathrm{mL})$ was added to the solution. Dose-response curve for streptokinase was drawn using streptokinase dilution preparation in $10 \mathrm{mM}$ Tris $-\mathrm{HCl}(\mathrm{pH}=7.4)$ by adding $0.1 \mathrm{mM} \mathrm{NaCl}$ and $1 \mathrm{mg} / \mathrm{mL}$ albumin. Different dilutions containing $0.5,1.0,2.0$ and 4.0 $\mathrm{IU} / \mathrm{mL}$ were assayed at $37^{\circ} \mathrm{C}$ in a microtiter plate. In the test samples, the reaction was performed by adding $60 \mu \mathrm{L}$ SK solution onto 40 $\mu \mathrm{L}$ of substrate solution. The final concentration of substrate S-2251 was $0.59 \mathrm{mM}$ and the final strength of buffer was $103.7 \mathrm{mM}$. After $20 \mathrm{~min}$, the reaction was stopped and the end point absorbance was measured at $405 \mathrm{~nm}$.

\section{Data analysis}

Minitab 16 software (Minitab Inc., USA) and Design Expert 7.0.0 were employed to design the experiment. Plackett-Burman design was employed to screen 10 different variables during 20 experiments. The results were used to accentuate the factors with the highest affectivity. ANOVA was used to assess the statistical parameters. The variables were analyzed by RSM at five different levels. The experimental design matrix consisted of a central composite design with six replications of the central points (all factor levels at 0 ). The analysis of experimental data was carried out statistically by regression method. The resulting equation was used to calculate the predicted amount of SK activity. The predicted and actual quantities of SK were compared using MiniTab software to analyze the reliability of the results. Using Design Expert 7.0.0 software, two-dimensional contour plots of the obtained results were produced. These plots were used to display the effect of different variables on the permeability of the 
membrane and hence, SK activity. Finally, the results of the experiments and analyses were fed into MiniTab software to predict the optimum concentrations of the critical factors and the resulting maximum SK activity.

\section{Experimental design}

To have a realistic modelling approach for higher secretory expression, the effecting factors should be known. In this regard, literature review revealed 10 factors (EDTA, peptone, glycine, triton X-100, glycerol, $\mathrm{K}_{2} \mathrm{HPO}_{4}, \mathrm{KH}_{2} \mathrm{PO}_{4}, \mathrm{CaCl}_{2}$, yeast extract and $\mathrm{NaCl}$ ) to be effective enhancers of the permeability of bacterial membrane and hence increase SK release into the culture medium. Each experiment was followed by an enzyme activity assay. SK activity was assayed using the chromogenic substrate method which is an end point method.

\section{Optimization of screened factors}

To enhance membrane permeability towards expressed recombinant SK, a design with five levels of study was used. In this regard, a RSMbased on the central composite design (CCD) was used to achieve optimized levels of glycine, triton X-100 and $\mathrm{Ca}^{2+}$. Three replicated experiments were performed for each section. Recombinant $E$. coli host cells (transformed with SK gene containing $\mathrm{pET} 21 \mathrm{~b}$ vector) without induction were used as negative control. The SK activity of the secreted recombinant protein was measured in different conditions by using the chromogenic substrate method (section 2.2). The results of enzyme activity assays was recorded in Table 5 in the column, 'Actual'. Finally, the activity of the recombinant SK was assayed in the culture medium at the optimum levels of glycine, triton $\mathrm{X}-100$ and $\mathrm{Ca}^{2+}$.

\section{RESULTS}

\section{Protein expression}

The recombinant bacterium was successfully constructed and cultured according to results of the SK over expression optimization experiment. Enzyme activity analysis of the total and extracellular (802 U/ml) SK activity revealed that the extracellular SK comprised only $10 \%$ of the total produced SK.

\section{Critical factors}

All factors considered to have an effective role in enhancing membrane permeability are listed in Table 1. Minimum-level (-1) and maximum-level
(+1) determinations of each factor are listed in Table 1 as a percentage of the culture medium.

Table 1: Ten nutrient screening using a PlackettBurman design

\begin{tabular}{|c|c|c|c|}
\hline \multicolumn{2}{|c|}{ Variable } & \multicolumn{2}{|c|}{ Percentage (\%) } \\
\hline $\begin{array}{l}\text { Nutrient } \\
\text { Code }\end{array}$ & Nutrient & Low (-1) & High (+1) \\
\hline A & EDTA & $2 \times 10^{-4}$ & $10 \times 10^{-4}$ \\
\hline B & Peptone & 0.5 & 1.5 \\
\hline C & Glycine & 0.6 & 2.25 \\
\hline $\mathrm{D}$ & Triton X-100 & 0.25 & 0.75 \\
\hline$E$ & Glycerol & 0.2 & 0.8 \\
\hline$F$ & $\mathrm{~K}_{2} \mathrm{HPO}_{4}$ & 1 & 2 \\
\hline $\mathrm{G}$ & $\mathrm{KH}_{2} \mathrm{PO}_{4}$ & 0.1 & 0.4 \\
\hline $\mathrm{H}$ & $\mathrm{CaCl}_{2}$ & 0.11 & 0.33 \\
\hline J & Yeast Extract & 0.5 & 2.5 \\
\hline K & $\mathrm{NaCl}$ & 0.5 & 1.5 \\
\hline
\end{tabular}

Table 2 lists the 20 experiments designed to screen for the most effective variables and results for enzyme activity of each experiment under the last column labelled 'results'. These results were further examined with MiniTab software. The minimum and maximum amounts of each factor were derived from results of previous studies. Factor with $\mathrm{P}$ value evaluation of $0.001 \leq P \leq 0.05$ (according to the software defaults) was assigned as very effective factor, while factor with P-value of $0.05 \leq \mathrm{P} \leq 0.1$ was assigned as effective one.

The results of statistical analyses (Table 3 ) introduced Glycine $(C)$ (P-value $=0.026)$, triton $\mathrm{X}-100(\mathrm{D})(p=0.035)$ and $\mathrm{Ca}^{2+}(\mathrm{H})(p=0.095)$ as the most effective factors in membrane permeability to release SK into the culture medium. Other factors showed the $p$-values > 0.1 and hence were not effective on SK secretion.

\section{Optimized culture}

Following selection of the critical factors for SK secretory expression (glycine, triton X-100 and $\left(\mathrm{Ca}^{2+}\right)$, it was necessary to determine optimum concentration of these selected factors. In this regard, the experimental range of each of the three variables was presented in five levels $(-\alpha,-$ $1,0,+1,+\alpha)$ (Table 4). The variables could be investigated in three levels $(-1,0,+1)$ but analysis of the factors in five levels can demonstrate the correctness of each factor range. Thereafter, 20 experiments, including six replications of the central points, were designed to optimize the screened factors (Table 5). In this step, it was tried to find the most effective concentration of three different factors (glycine, triton $\mathrm{X} 100$ and $\mathrm{CaCl}_{2}$ ) on extracellular SK expression. 
Table 2: Screening of effective factors for secreted streptokinase activity by using Plackett-Burman experimental design matrix

\begin{tabular}{|c|c|c|c|c|c|c|c|c|c|c|c|}
\hline & A & B & C & D & E & $F$ & $\mathbf{G}$ & $\mathrm{H}$ & $\mathbf{J}$ & $\mathrm{K}$ & \\
\hline $\begin{array}{l}\text { Run } \\
\text { order }\end{array}$ & 占 & $\begin{array}{l}\stackrel{\Phi}{c} \\
\stackrel{0}{0} \\
\stackrel{0}{0} 0 \\
0\end{array}$ & $\frac{\mathscr{D}}{\frac{\mathrm{S}}{\mathrm{N}}}$ & 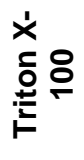 & 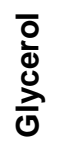 & 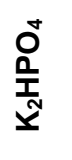 & $\begin{array}{l}\text { O' } \\
\frac{N}{\mathbf{N}} \\
\frac{1}{x}\end{array}$ & $\stackrel{+}{\mathbb{N}}$ & 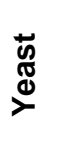 & $\begin{array}{l}\overline{\mathbb{Z}} \\
\mathbf{z}\end{array}$ & Result \\
\hline 1 & 1 & -1 & 1 & 1 & -1 & -1 & -1 & -1 & 1 & -1 & 1095 \\
\hline 2 & 1 & 1 & -1 & 1 & 1 & -1 & -1 & -1 & -1 & 1 & 1020 \\
\hline 3 & -1 & 1 & 1 & -1 & 1 & 1 & -1 & -1 & -1 & -1 & 825 \\
\hline 4 & -1 & -1 & 1 & 1 & -1 & 1 & 1 & -1 & -1 & -1 & 1260 \\
\hline 5 & 1 & -1 & -1 & 1 & 1 & -1 & 1 & 1 & -1 & -1 & 1065 \\
\hline 6 & 1 & 1 & -1 & -1 & 1 & 1 & -1 & 1 & 1 & -1 & 600 \\
\hline 7 & 1 & 1 & 1 & -1 & -1 & 1 & 1 & -1 & 1 & 1 & 1320 \\
\hline 8 & 1 & 1 & 1 & 1 & -1 & -1 & 1 & 1 & -1 & 1 & 405 \\
\hline 9 & -1 & 1 & 1 & 1 & 1 & -1 & -1 & 1 & 1 & -1 & 960 \\
\hline 10 & 1 & -1 & 1 & 1 & 1 & 1 & -1 & -1 & 1 & 1 & 1215 \\
\hline 11 & -1 & 1 & -1 & 1 & 1 & 1 & 1 & -1 & -1 & 1 & 720 \\
\hline 12 & 1 & -1 & 1 & -1 & 1 & 1 & 1 & 1 & -1 & -1 & 1065 \\
\hline 13 & -1 & 1 & -1 & 1 & -1 & 1 & 1 & 1 & 1 & -1 & 855 \\
\hline 14 & -1 & -1 & 1 & -1 & 1 & -1 & 1 & 1 & 1 & 1 & 660 \\
\hline 15 & -1 & -1 & -1 & 1 & -1 & 1 & -1 & 1 & 1 & 1 & 480 \\
\hline 16 & -1 & -1 & -1 & -1 & 1 & -1 & 1 & -1 & 1 & 1 & 570 \\
\hline 17 & 1 & -1 & -1 & -1 & -1 & 1 & -1 & 1 & -1 & 1 & 315 \\
\hline 18 & 1 & 1 & -1 & -1 & -1 & -1 & 1 & -1 & 1 & -1 & 555 \\
\hline 19 & -1 & 1 & 1 & -1 & -1 & -1 & -1 & 1 & -1 & 1 & 360 \\
\hline 20 & -1 & -1 & -1 & -1 & -1 & -1 & -1 & -1 & -1 & -1 & 165 \\
\hline
\end{tabular}

Table 3: Statistical analysis from the results of Plackett-Burman design for screening of medium components

\begin{tabular}{lcccc}
\hline Factor & Medium component & Effect & T-value & $\boldsymbol{P}$-value \\
\hline A & EDTA & 180.00 & 1.69 & 0.124 \\
B & Peptone & -27.00 & -0.25 & 0.805 \\
C & Glycine & 282.00 & 2.65 & $\mathbf{0 . 0 2 6}$ \\
D & Triton X-100 & 264.00 & 2.49 & $\mathbf{0 . 0 3 5}$ \\
E & Glycerol & 189.00 & 1.78 & 0.109 \\
F & K2HPO4 & 180.00 & 1.69 & 0.124 \\
G & KH2PO4 & 144.00 & 1.36 & 0.208 \\
H & Ca & -198.00 & -1.86 & $\mathbf{0 . 0 9 5}$ \\
J & Yeast Extract & 111.00 & 1.04 & 0.323 \\
K & $\mathrm{NaCl}$ & -138.00 & -1.30 & 0.226 \\
\hline
\end{tabular}

$0.001 \leq P$ value $\leq 0.1$ is more effective factors, hence $C=$ Glycine and $D=$ Triton $X-100$ and $H=\mathrm{Ca}^{2+}$ are more important factors

Table 4: Experimental range of variables and coded values of three variables used in Central Composite Design

\begin{tabular}{lcccccc}
\hline Variable level & Component & \multicolumn{5}{c}{ Level } \\
\cline { 3 - 6 } & & $-\boldsymbol{\alpha}$ & $\mathbf{- 1}$ & $\mathbf{0}$ & $\mathbf{+ 1}$ & $\mathbf{+ \alpha}$ \\
\hline $\mathrm{A}$ & Glycine (\%) & 0.039 & 0.6 & 1.425 & 2.25 & 2.811 \\
$\mathrm{~B}$ & Triton X-100 (\%) & 0.08 & 0.25 & 0.50 & 0.75 & 0.92 \\
$\mathrm{C}$ & $\mathrm{CaCl}_{2}(\%)$ & 0.0352 & 0.11 & 0.22 & 0.33 & 0.4048 \\
\hline
\end{tabular}

This table provides results for SK activity under the 'Actual' column, while predicted amounts are shown under the 'Predicted' column. Predicted levels of SK activity, as functions of glycine (A), triton X-100 (B) and $\mathrm{Ca}^{2+}(\mathrm{C})$ were fitted with a second-order equation which provided the levels of SK activity (Eq 1).
$\mathrm{Y}$ (Streptokinase activity $\mathrm{U} / \mathrm{mL})=+5516.48-$ $(375.2 \mathrm{~A})-(73.6017 \mathrm{~B})+(22.7601 \mathrm{C})-$ $\left(248.755 A^{2}\right)-\left(423.234 B^{2}\right)-\left(498.011 C^{2}\right)-$ $\left(1.86435 \times 10^{-14} A B\right)-\left(6.82826 \times 10^{-14} A C\right)+$ $\left(2.54278 \times 10^{-14} \mathrm{BC}\right)$ 
Table 5: CCD with measured an--d predicted responses with transcription level of SK as a response

\begin{tabular}{|c|c|c|c|c|c|}
\hline $\begin{array}{l}\text { Run } \\
\text { no. }\end{array}$ & Factor A & Factor B & Factor C & $\begin{array}{r}\text { Variatio } \\
\text { a }\end{array}$ & $\begin{array}{l}\text { ptokinase } \\
\text { (ml) }\end{array}$ \\
\hline & $\begin{array}{c}\text { Glycine } \\
\text { percentage }\end{array}$ & $\begin{array}{l}\text { Triton X-100 } \\
\text { percentage }\end{array}$ & $\begin{array}{c}\mathrm{CaCl}_{2} \\
\text { percentage }\end{array}$ & Actual & Predicted \\
\hline 1 & -1 & -1 & -1 & 3447 & 3182 \\
\hline 2 & 1 & -1 & -1 & 2757 & 2681 \\
\hline 3 & -1 & 1 & -1 & 3180 & 3084 \\
\hline 4 & 1 & 1 & -1 & 2491 & 2583 \\
\hline 5 & -1 & -1 & 1 & 3400 & 3212 \\
\hline 6 & 1 & -1 & 1 & 2710 & 2712 \\
\hline 7 & -1 & 1 & 1 & 3133 & 3114 \\
\hline 8 & 1 & 1 & 1 & 2444 & 2614 \\
\hline 9 & -1.68 & 0 & 0 & 3337 & 3629 \\
\hline 10 & 1.68 & 0 & 0 & 2945 & 2788 \\
\hline 11 & 0 & -1.68 & 0 & 2695 & 2962 \\
\hline 12 & 0 & 1.68 & 0 & 2930 & 2797 \\
\hline 13 & 0 & 0 & -1.68 & 2554 & 2713 \\
\hline 14 & 0 & 0 & 1.68 & 2789 & 2764 \\
\hline 15 & 0 & 0 & 0 & 3651 & 3678 \\
\hline 16 & 0 & 0 & 0 & 3739 & 3678 \\
\hline 17 & 0 & 0 & 0 & 3672 & 3678 \\
\hline 18 & 0 & 0 & 0 & 3616 & 3678 \\
\hline 19 & 0 & 0 & 0 & 3678 & 3678 \\
\hline 20 & 0 & 0 & 0 & 3733 & 3678 \\
\hline
\end{tabular}

Analysis of variance (ANOVA) for the response surface demonstrate that the regression is statistically significant at $99 \%(\mathrm{p}<0.05)$ confidence level. If the values of "Prob $>F$ " was less than 0.0500 it means that model terms are significant. But values greater than 0.1000 are not significant. In this case $A, A^{2}, B^{2}$ and $C^{2}$ are significant model terms (Table 6 ). So $B, C$ and all interactions are not significant. It means that there are no effective interactions between these three different factors.

Model F-value of 10.01 indicates that the model is significant. The chance that a "Model FValue" this large could occur due to noise is just $0.06 \%$. Comparison between actual and predicted response values show agreement $\left(R^{2}\right.$ $=0.9)$ (Figure 1).

The effect of each factor on SK activity was depicted by two-dimensional contour plot (Figure 2, 3 and 4). Optimum levels of the critical factors (glycine $=0.878 \%$, triton $\mathrm{X}-100=0.479 \%$ and $\mathrm{CaCl}_{2}=0.222 \%$ ), along with the predicted maximum SK activity $(5661.3747 \mathrm{U} / \mathrm{ml})$ are presented in Figure -5 . The optimum levels are acceptable because all of them are in selected ranges. Finally, activity assay of SK (5824 U/ml) cultured in optimum levels of glycine, triton $X$ 100 and $\mathrm{Ca}^{2+}$ confirmed the maximum activity predictions and it shows highest level of extracellular SK activity, in comparison to other studies (Table 7).

Table 6: Analysis of variance (ANOVA) for response surface quadratic model for the streptokinase production

\begin{tabular}{lcccc}
\hline Source & Sum of squares & DF & F-value & Prob > F \\
\hline Model & $8.012 \mathrm{E}+006$ & 9 & 10.01 & 0.0006 \\
A-Glycine \% & $1.923 \mathrm{E}+006$ & 1 & 21.63 & $\mathbf{0 . 0 0 0 9}$ \\
B-Triton X-100\% & 73858.37 & 1 & 0.83 & 0.3835 \\
C-CaCl2\% & 7112.91 & 1 & 0.080 & 0.7831 \\
AB & 0.000 & 1 & 0.000 & 1.0000 \\
AC & 0.000 & 1 & 0.000 & 1.0000 \\
BC & 0.500 & 1 & $5.624 \mathrm{E}-006$ & 0.9982 \\
A $^{2}$ & $8.906 E+005$ & 1 & 10.02 & $\mathbf{0 . 0 1 0 1}$ \\
$\mathrm{B}^{2}$ & $2.580 \mathrm{E}+006$ & 1 & 29.01 & $\mathbf{0 . 0 0 0 3}$ \\
$\mathrm{C}^{2}$ & $3.575 \mathrm{E}+006$ & 1 & 40.20 & $<0.0001$ \\
Residual & $8.891 \mathrm{E}+005$ & 10 & & 0.0007 \\
Lack of Fit & $8.635 \mathrm{E}+005$ & 5 & 33.70 & \\
Pure Error & 25622.83 & 5 & & \\
Cor Total & $8.901 \mathrm{E}+006$ & 19 & & \\
\hline
\end{tabular}




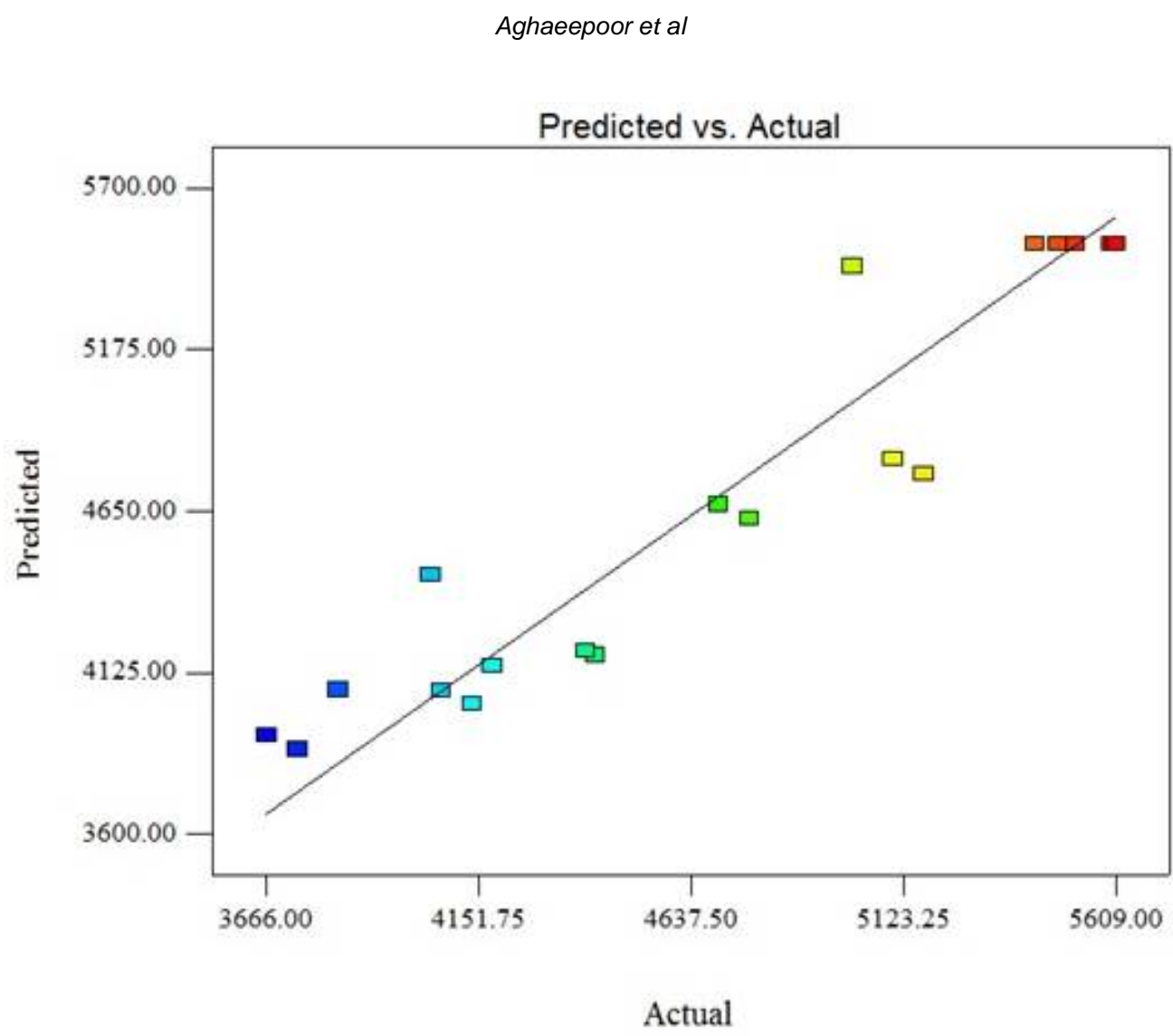

Figure 1: Predicted response versus actual value

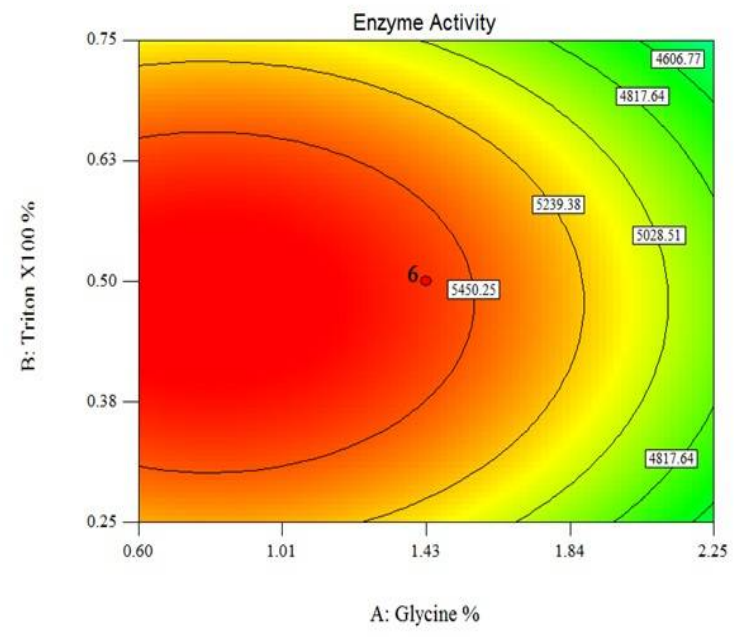

(A)

Figure 2: Contour plot $(A)$ and $3 D$ response surface $(B)$ for Streptokinase production by $E$. coli that show the effect of glycine and triton X-100 concentration on secreted SK activity.

\section{DISCUSSION}

Production yield of a recombinant protein can be affected by several factors. Developing novel methods for enhancement of secreted active recombinant SK production yield have important financial significance. Accordingly, the analysis in this study were done to determine the most effective chemical factors and their optimum amounts to permeabilize the $E$. coli cell membrane for secretion of a recombinant SK

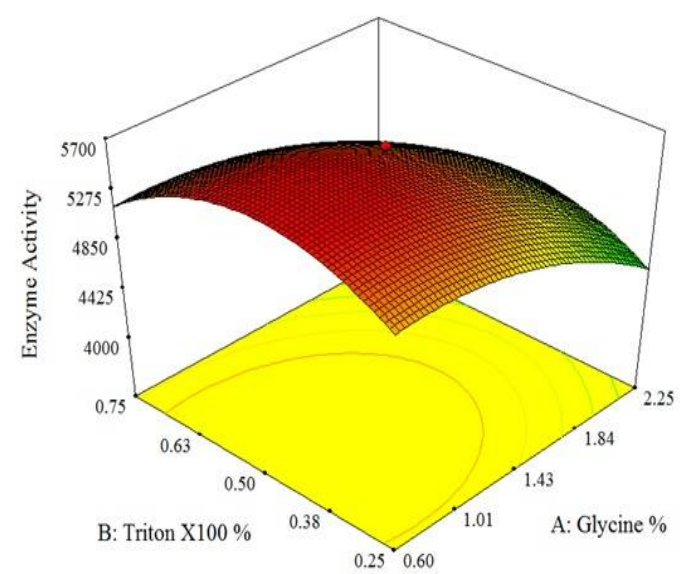

(B)

protein. The process was successfully optimized for periplamic expression.

Extracellular release of recombinant proteins from the periplasm seems to be a relatively ideal and rational solution for extracellular protein production. The reportedly low rate of SK secretion $(10 \%)$ in this expression system accentuates the necessity of increasing SK translocation from the cytoplasm to the culture medium. The inner membrane can be crossed using various signal sequences such as PelB, 


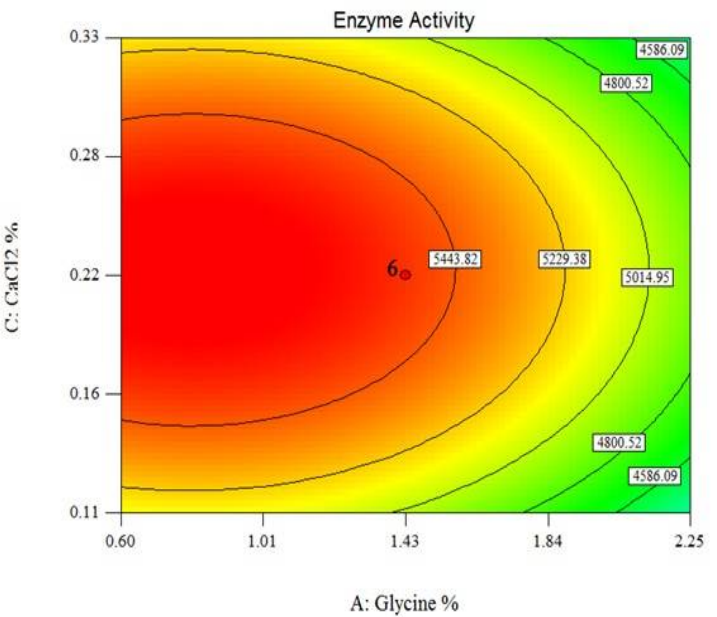

(A)

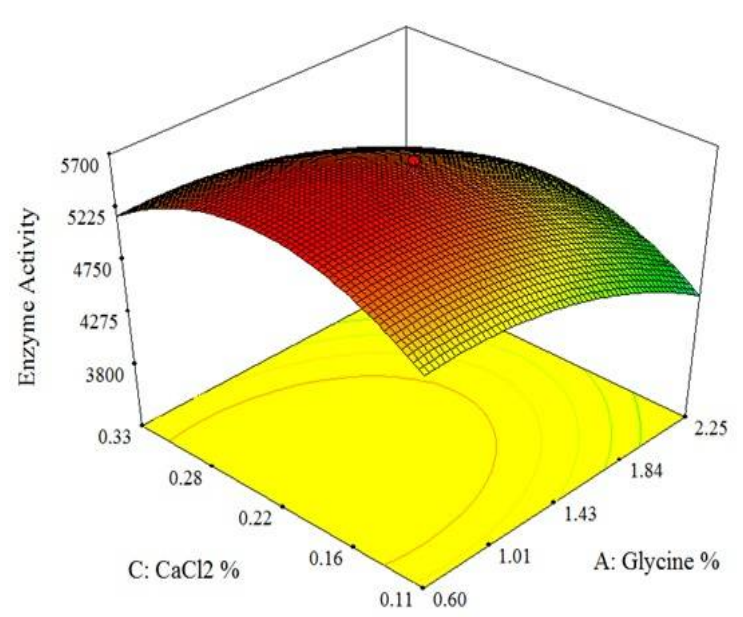

(B)

Figure 3: Contour plot $(A)$ and $3 D$ response surface $(B)$ for Streptokinase production by $E$. coli that show the effect of glycine and $\mathrm{CaCl}_{2}$ concentration on secreted SK activity.

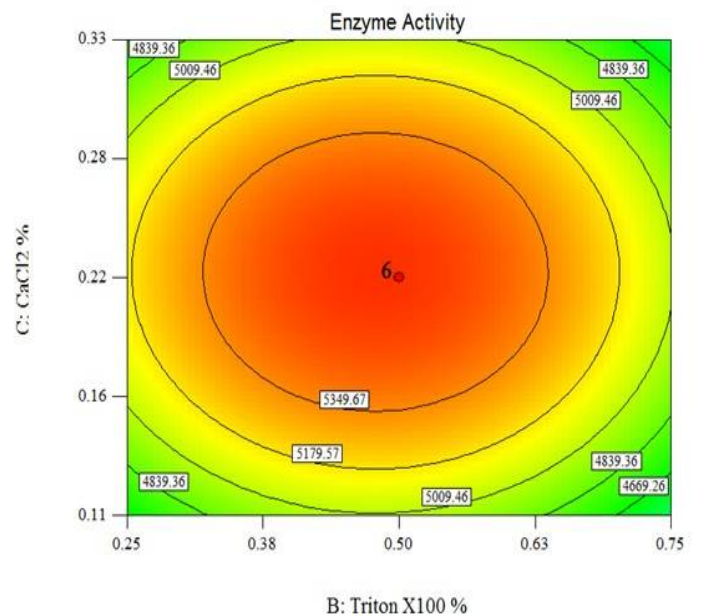

(A)

Figure 4: Contour plot $(A)$ and $3 D$ response surface $(B)$ for Streptokinase production by $E$. coli that show the effect of triton $\mathrm{X}-100$ and $\mathrm{CaCl}_{2}$ concentration on secreted SK activity.

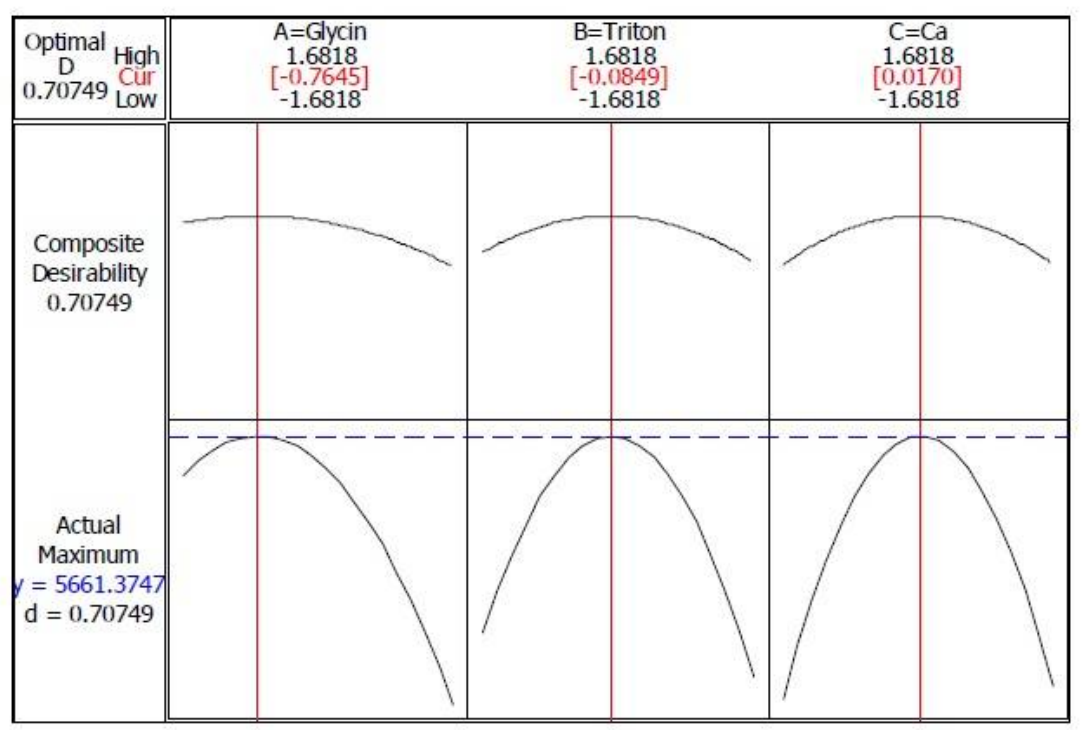

Figure 5: Optimization plot for highest secreted SK activity 
which could translocate the protein to the periplasm through a sec-dependent secretion pathway [7]. The outer membrane barrier could be dealt with by chemical permeabilization.

For determination of the most effective components of the culture medium, RSM method was used to design the experiments. Optimization of medium supplements could be achieved by various approaches. This method has been widely utilized in biotechnological processes for bioprocess optimization exploring several interplaying factors [16]. Placket Burman software was selected to design these experiments because it minimises the number of experiments, is realistic and could analyze different factors and their interactions simultaneously.

It has been demonstrated that glycine induces morphological changes and cell lysis $[17,18]$. Hammes et al reports that glycine could be incorporated into the peptidoglycan precursors and peptidoglycan [19]. Research suggests that since glycine-containing precursors are poor substrates in transpeptidation reactions, a high percentage of muropeptides remains uncrosslinked [19]. Therefore, it increases membrane permeability for recombinant protein. Fu et al reports that the chemical triton $\mathrm{X}-100$ could release recombinant protein to the extracellular medium by permeabilization of the cells [20]. Triton $\mathrm{X}-100$ is reported to inhibit synthesis of membrane phospholipids, which would promote extracellular translocation of recombinant proteins by affecting integrity of the cell membrane [12].

Several lines of evidence indicate that triton $X$ 100 mainly effects the inner membrane [21]. Aside from their individual ability to permeate the E. coli membrane, Bin Lee et al reveals a potential mechanism in the interaction effect of glycine and triton X-100 [12]. Research has shown that combination of glycine and triton $X$ 100 could result in drastically increased permeability of both inner and outer membranes [12]. More interestingly, Li et al reveals that glycine and $\mathrm{Ca}^{2+}$ can markedly enhance secretion of recombinant proteins to extracellular medium [13]. However, Li et al demonstrates that $\mathrm{Ca}^{2+}$ did not alter directly total translocation rates of the recombinant protein through the membrane barriers. $\mathrm{Ca}^{2+}$ helped to compensate for the adverse effects of glycine treatment through reduced cell number and viability by promoting healthy cell growth by maintaining sufficient membrane permeability [13].
In light of these observations, it can be concluded that SK secretion was mostly effected by glycine, triton $\mathrm{X}-100$ and $\mathrm{Ca}^{2+}$ due their specific mechanism of interactions. It seems that glycine and triton $\mathrm{X}-100$ were responsible for inner and outer membrane permeability, while $\mathrm{Ca}^{2+}$ apparently provided support for healthy cell growth and cell viability, which was harmed by the adverse effects of glycine and triton X-100. The collective effect of the interplay between these factors is successful permeability of the $E$. coli membrane for SK secretion that was confirmed by enzyme activity assays. Moreover, permeability of the inner membrane may facilitate translocation of expressed SK into the preplasmic space and lead to more soluble SK production and increased enzyme activity.

There are several reports on different approaches to extracellular expression of SK. However, the significant increment of the extracellular SK activity, in comparison to other studies [22-26], confirms robustness of the method employed in these experiments (Table 7). Although translocation of recombinant SK across the bacterial membrane was significantly increased (> 7-fold) following optimization, the problem of non-specific protein secretion and adverse effects of selected chemical factors on produced enzyme activity needs further investigation.

\section{CONCLUSION}

Optimization of media conditions for secretory expression of streptokinase in $E$. coli has been successfully conducted by RSM. Glycine, triton $\mathrm{X}-100$ and $\mathrm{Ca}^{2+}$ are the most effective chemical factors in terms of increase in membrane permeability, with a 7-fold increase in the amount of secreted recombinant protein. To the best of our knowledge, this is the first study to determine the essential chemicals of a culture medium for SK release and optimization.

\section{DECLARATIONS}

\section{Acknowledgement}

The authors are grateful for the financial support provided by Semnan University of Medical Sciences (no. A-10-100-8) and Gene Transfer Pioneers Company (no. 1223337). They also thank Dr Seyed Bahman Momen for his assistance with data analysis.

\section{Conflict of Interest}

No conflict of interest associated with this work. 


\section{Contribution of Authors}

The authors declare that this work was done by the authors named in this article and all liabilities pertaining to claims relating to the content of this article will be borne by them.

\section{Open Access}

This is an Open Access article that uses a funding model which does not charge readers or their institutions for access and distributed under the terms of the Creative Commons Attribution License (http://creativecommons.org/licenses/by/ 4.0) and the Budapest Open Access Initiative (http://www.budapestopenaccessinitiative.org/rea d), which permit unrestricted use, distribution, and reproduction in any medium, provided the original work is properly credited.

\section{REFERENCES}

1. Longstaff $C$, Whitton $C$. A survey of streptokinase products shows inconsistencies in the quality of thrombolytic products used worldwide. XIX ISTH Congress, Birmingham, UK 2003.

2. Banerjee A, Chisti Y, Banerjee UC. Streptokinase-a clinically useful thrombolytic agent. Biotechnol Adv 2004; 22: 287-307.

3. Couto LT, Donato JL, de Nucci G. Analysis of five streptokinase formulations using the euglobulin lysis test and the plasminogen activation assay. Braz J Med Biol Res 2004; 37: 1889-1894.

4. Lee SY. High cell-density culture of Escherichia coli. Trends Biotechnol 1996; 14: 98-105.

5. Jeang $C L$, Lin DG, Hsieh SH. Characterization of cyclodextrin glycosyltransferase of the same gene expressed from Bacillus macerans, Bacillus subtilis, and Escherichia coli. J Agric Food Chem 2005; 53: 63016304.

6. Kim SG, Kweon DH, Lee DH, Park YC, Seo JH. Coexpression of folding accessory proteins for production of active cyclodextrin glycosyltransferase of Bacillus macerans in recombinant Escherichia coli. Protein Expr Purif 2005; 41: 426-432.

7. Choi JH, Lee SY. Secretory and extracellular production of recombinant proteins using Escherichia coli. App Microbiol Biotechnol 2004; 64: 625-635.

8. Koebnik $R$, Locher KP, Van Gelder $P$. Structure and function of bacterial outer membrane proteins: barrels in a nutshell. Mol Microbiol 2000; 37: 239-253.

9. Mergulhao FJ, Summers DK, Monteiro GA. Recombinant protein secretion in Escherichia coli. Biotechnol Adv 2005; 23: 177-202.

10. Rinas $U$, Hoffmann $F$. Selective leakage of host-cell proteins during high-cell-density cultivation of recombinant and non-recombinant Escherichia coli. Biotechnol Prog 2004; 20: 679-687.
11. Shokri A, Sanden AM, Larsson G. Cell and process design for targeting of recombinant protein into the culture medium of Escherichia coli. Appl Microbiol Biotechnol 2003; 60: 654-664.

12. Li B, Wang L, Su S, Chen S, Li Z, Chen J, Wu J. Glycine and Triton $X-100$ enhanced secretion of recombinant $\alpha$ CGTase mediated by OmpA signal peptide in Escherichia coli. Biotechnol Bioproc E 2012; 17: 11281134.

13. Li ZF, Li B, Liu ZG, Wang M, Gu ZB, Du GC, Wu J, Chen J. Calcium leads to further increase in glycine-enhanced extracellular secretion of recombinant alpha-cyclodextrin glycosyltransferase in Escherichia coli. J Agric Food Chem 2009; 57: 6231-6237.

14. Aghaeepoor M, Akbarzadeh A, Kobarfard F, Shabani AA, Dehnavi E, Jamshidi Aval S, Akbari Eidgahi MA. Optimization and high level production of recombinant synthetic Streptokinase in E. coli using Response Surface Methodology. IJPR 2017; In press.

15. Sands $D$, Whitton CM, Longstaff $C$. International collaborative study to establish the 3rd International Standard for Streptokinase. J Thromb Haemost 2004; 2: 1411-1415.

16. Bas D, Boyaci IH. Modeling and optimization I: Usability of response surface methodology. J Food Eng 2007; 78: 836-845.

17. Kaderbhai N, Karim A, Hankey W, Jenkins G, Venning J, Kaderbhai MA. Glycine-induced extracellular secretion of a recombinant cytochrome expressed in Escherichia coli. Biotechnol Appl Biochem 1997; 25(1): 53-61.

18. Yang J, Moyana T, MacKenzie S, Xia Q, Xiang J. One hundred seventy-fold increase in excretion of an FV fragment-tumor necrosis factor alpha fusion protein (sFV/TNF-alpha) from Escherichia coli caused by the synergistic effects of glycine and triton X-100. Appl Environ Microbiol 1998; 64: 2869-2874.

19. Hammes W, Schleifer KH, Kandler O. Mode of action of glycine on the biosynthesis of peptidoglycan. J Bacteriol 1973; 116: 1029-1053.

20. $F u X Y$, Tong $W Y$, Wei DZ. Extracellular production of human parathyroid hormone as a thioredoxin fusion form in Escherichia coli by chemical permeabilization combined with heat treatment. Biotechnol Prog 2005; 21: 1429-1435.

21. Woldringh CL. Lysis of the cell membrane of Escherichia coli K12 by ionic detergents. Biochim Biophys Acta 1970; 224: 288-290.

22. Goyal D, Sahni G, Sahoo DK. Enhanced production of recombinant streptokinase in Escherichia coli using fedbatch culture. Bioresour Technol 2009; 100: 4468-4474.

23. Hyoung Lee S, Chul Kim I, Hee Bae K, Myung Byun S. Enhanced production and secretion of streptokinase into extracellular medium in Escherichia coli by removal of 13 N-terminal amino acids. Biotechnol Lett 1997; 19: 151-154.

24. Ko JH, Park DK, Kim IC, Hyoung Lee S, Myung Byun S. High-level expression and secretion of streptokinase in Escherichia coli. Biotechnol Lett 1995; 17: 1019-1024.

Trop J Pharm Res, November 2017; 16(11): 2575 
Aghaeepoor et al

25. Malke H, Ferretti JJ. Streptokinase: cloning, expression, and excretion by Escherichia coli. Proc Natl Acad Sci U S A 1984; 81: 3557-3561.
26. Pratap J, Kaur J, RajaMohan G, Singh D, Dikshit KL. Role of $\mathrm{N}$-terminal domain of streptokinase in protein transport. Biochem Biophys Res Commun 1996; 227: 303-310. 